European Journal of Pragmatism and American Philosophy

VIII-1 | 2016

Dewey's Democracy and Education as a Source of and a Resource for European Educational Theory and Practice

\title{
Narrowing Down Education
}

A Deweyan Perspective on the EU Educational Framework

\section{Vasco D'Agnese}

\section{OpenEdition}

\section{Journals}

Electronic version

URL: http://journals.openedition.org/ejpap/442

DOI: $10.4000 /$ ejpap.442

ISSN: 2036-4091

Publisher

Associazione Pragma

\section{Electronic reference}

Vasco D'Agnese, « Narrowing Down Education », European Journal of Pragmatism and American Philosophy [Online], VIII-1 | 2016, Online since 20 July 2016, connection on 01 May 2019. URL : http:// journals.openedition.org/ejpap/442 ; DOI : 10.4000/ejpap.442

This text was automatically generated on 1 May 2019.

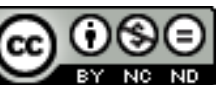

Author retains copyright and grants the European Journal of Pragmatism and American Philosophy right of first publication with the work simultaneously licensed under a Creative Commons Attribution-

NonCommercial-NoDerivatives 4.0 International License. 


\title{
Narrowing Down Education
}

\author{
A Deweyan Perspective on the EU Educational Framework
}

\author{
Vasco D'Agnese
}

\section{Introduction}

1 At least since the Lisbon Memorandum on Lifelong Learning (EU 2000), European education has been increasingly framed in terms of a neoliberal rallying cry. This "neoliberal cascade" (Connell 2013) has widely affected education and schooling in Europe, pushing educational institutions and processes and even what we may call "educational subjectivities" (of both teachers and students) towards a significant transformation (Ball 2003). Such a transformation - and this is my point - is anything but benign: it implies a lack, if not an eclipse, of invaluable educational features such as critical agency, democratic sharing among all the actors of educational processes and practices, and meaning creation. In my paper, I wish to address this issue in the light of Deweyan thought and educational philosophy, mainly in reference to his masterpiece Democracy and Education. In particular, I focus on a) the well-known Deweyan understanding of democracy as "a mode of associated living, of conjoint communicated experience" (MW 9: 93); ${ }^{1}$ and b) on meaning creation and its relationship to educational processes and practices. As we know, Dewey related the growth and wealth of democracy to "varied points of shared common interest," "mutual interests" and "freer interaction between social groups" (MW 9: 92). Importantly, such features are not only basic features of democracy but are also, according to the Deweyan challenge to any form of dualism, means of pursuing individual and collective growth. The failure to recognise such a transactional relationship results in an impoverished conception of education at the individual and collective levels - and indeed, such a division between the lives of individuals and the life of community does not make sense within a Deweyan framework. Thus, I wish to argue that only through a different conception of education, one in which education is not rationed, individualised or commodified, do we find the clear sense of "unattained possibilities" (LW 1: 143) that in turn make living worthwhile. I also argue 
that the EU framework on education is inconsistent in that it is not able to fulfil its own goals.

This paper is organised into three sections. In the first section, I analyse key documents in European educational politics. Starting with the Lisbon Memorandum on Lifelong Learning and continuing with Europe 2020 and Rethinking Education, I explicate basic features of the European framework on education and argue why and how it is actually problematic. In this section, I also engage with critical literature on what we may call the neoliberal turn in education. In the second and third sections, I specifically address what I see as the main weaknesses of the EU framework on education while suggesting a different perspective on educational processes. More specifically, in the second section, I address the EU propensity to conceive of education as adaptation - both individuals and educational systems are, in the EU's words, expected to "adapt [to] the demands of the knowledge society" (European Council 2000: § 25). In the third section, I discuss the EU's tendency toward the individuation and atomisation of educational practices, whereby educational actors - individuals as well as institutions - are viewed as isolated and distinct elements, each pursuing their own goals. Finally, I argue that these two tendencies - adaptation and atomisation - taken together entail a narrowing down of the democratic and ethical dimensions of educational processes and practices. In other words, these tendencies become a threat to democracy when they are imposed on schooling and education.

\section{How Does the EU Conceive of Education?}

3 Although the history of European co-operation on educational policy dates back to the early 1960s, the impact and scope of this cooperation "has moved with increased velocity in recent years" (Lawn \& Lingard 2002: 290). According to Lawn and Lingard, "like an emerging behemoth, the European area of education policy has gradually involved more and more system administrators in national agencies, cities and regions" (Ibid.: 290). Importantly, such influential processes has affected the educational system at all scales, from the Continental to the national and regional levels; even individual schools and teachers are required to conform to the EU framework on education (Lawn \& Lingard 2002; Ball 2003; Clarke 2012; and Connell 2013).

Several scholars have discussed this effect, and EU gestures have been described and labelled in various ways, ranging from those of "creeping extension" (Field 1998: 26) to "covert activity" (Ryba 1992: 11) and even to cases of "semi-clandestine perversion" (No'voa 2000: 33). ${ }^{2}$ Criticisms of this underlying educational framework have also been raised in the fields of educational philosophy and theory and mainly highlight the narrow view of education emerging from such a framework and its undemocratic effects on education and schooling (cf. Burbules \& Torres 2000; Biesta 2006, 2015a, 2015b; Simons 2006; and Masschelein \& Simons 2008). It is outside the scope of this paper to comprehensively analyse the bulk of scholarly work on this issue - not least because such criticisms belong to a broad variety of conceptual frameworks and perspectives; nevertheless, some engagement is required for my own purposes. In this section I shall focus on what I believe are the most critiqued effects of the neoliberal framework on educational policies, and I show how EU educational policies penetrate such a framework. More specifically, I wish to show how the EU educational framework exhibits the following: a) a strong orientation towards adaptation and a definite view of education as a 
means of human capital formation: both individuals and educational systems are expected to adapt "to the demands of the knowledge society" (European Council 2000: $\S 25)$; and b) an individuation or atomisation of educational practices, whereby educational actors - individuals as well as institutions - are viewed as isolated and distinct elements, each one pursuing its own path and eclipsing the democratic and ethical dimensions of educational processes and practices. In making my point, let me begin with the introductory statement of what is known as the Lisbon Memorandum on Lifelong Learning. I quote three significant passages and then provide my comments:

The European Council held in Lisbon in March 2000 marks a decisive moment for the direction of policy and action in the European Union. Its conclusions affirm that Europe has indisputably moved into the Knowledge Age, with all that this will imply for cultural, economic and social life. Patterns of learning, living and working are changing apace. This means not simply that individuals must adapt to change, but equally that established ways of doing things must change too. The conclusions of the Lisbon European Council confirm that the move towards lifelong learning must accompany a successful transition to a knowledge-based economy and society. Therefore, Europe's education and training systems are at the heart of the coming changes. They too, must adapt. (EU 2000: 3; emphasis added)

The conclusion is that, above all, education and training systems must adapt to the new realities of the 21st century. (Ibid.: 6)

Europe's education and training systems need to adapt both to the demands of the knowledge society and to the need for an improved level and quality of employment. (European Council 2000: § 25)

5 In these quoted passages, it is above all important to note how the neoliberal framework is taken for granted. 'Social life' is narrowed down to its economic features: the "knowledge-based economy" and "the need for an improved level and quality of employment." This implies that knowledge is defined and consumed by its monetary value and that human beings are conceived of and viewed as human capital. Such an approach is both characteristic of and functional for neoliberalism. As Connell puts it,

Neoliberalism has a definite view of education, understanding it as human capital formation. It is the business of forming the skills and attitudes needed by a productive workforce - productive in the precise sense of producing an evergrowing mass of profits for the market economy. "Human capital" is a metaphor, and in itself too narrow. However, this economistic idea does catch an important feature of education, that it is a creative process oriented to the future. (Connell 2013: 104)

6 Finally, there is no competition between or acknowledgment of different perspectives on society and education; the competition is occurring within the system, namely, between schools, teachers and students, and not between different systems or models of society. In such a framework, individuals and institutions are required to continually strive to enhance their positions as established in various ranking and league tables (cf. Alexander 2011; and Au 2008). From an educational point of view, this implies that the only possible option for education is for it to adjust itself to the system's requirements; as it is explicitly stated that "education and training systems must adapt to the new realities of the 21st century." Individuals too, as is made clear, "must adapt to change." We are not far from truth in saying that at the very heart of such a stance is the desire to subsume every educational aim, possibility, or value into its own model. Moreover, such a stance is predetermined and is evident in itself; it is not a matter of on-going discussion. In this way, EU "educational" policies, de facto, tend to expropriate subjects and communities of their knowledge and culture, denying their legitimacy. We come to see how the EU's 
notion of education is ultimately exclusive rather than inclusive. At the risk of being pedantic, I wish to clarify this issue: the EU states that individuals must be included in educational politics, thus contributing to the development of society - which has more than a passing similarity to the No Child Left Behind act. ${ }^{3}$ However, the very problem resides in the fact that individuals - both children and adults - are not included in the first place because the EU statement, so to speak, leaves no room for transformations or transactions among individuals and environments. To be included, individuals must previously meet certain requirements, and if they do not, they must adjust themselves first to be included in educational paths. Of course, education also entails socialisation and the need for judgment, and it is concerned with providing individuals with the necessary skills for living in society - the well-known paradox of educational freedom and educational authority (see Biesta 2009, 2010). However, such a strong orientation towards a pre-established qualification of individuals raises serious concerns regarding the commitment of education to democracy and newness. To the extent that education is preconceived throughout, it is difficult to envisage how critical agency, which is certainly a pivotal feature of education, can be pursued.

7 Strong commitments to the labour market and the narrowing down of education - and living - to its economic dimension are reinforced in Europe 2020: A strategy for smart, sustainable and inclusive growth. In this document, which forms the basis for EU policies from 2010 to the next decade, we find the following:

Smart growth: developing an economy based on knowledge and innovation. [...] "Youth on the move" to enhance the performance of education systems and to facilitate the entry of young people to the labour market. (European Commission 2010: 5)

To ensure that the competences required to engage in further learning and the labour market are acquired and recognised throughout general, vocational, higher and adult education and to develop a common language and operational tool for education/training and work. (Ibid.: 19)

8 Once again, we find the same implicit assumptions. The only possible option available is for education to follow and adjust; it is a means of facilitating "the entry of young people to the labour market"; the first aim of all actors involved in educational paths is "to ensure that the competences required to engage in further learning and the labour market are acquired and recognised" - which is why education is all-consumed by learning (cf. Biesta 2006). I wish to highlight that the instrumental value of education is not only a problem in itself, but it also carries the connotation of an "atomisation" of education at all levels, thus pushing towards a restriction of educational opportunities, a concept referenced directly in the following:

Instrumentalism is thus linked to another tendency in neoliberal education policy, a shift towards individuation or atomisation, whereby educational institutions and agents are viewed as isolated and distinct elements, with little or no recognition of how they also comprise larger systems or structures, or of how the meaning of each can only be understood in relation to that larger whole. This individualisation is evident in the frequent lack of recognition of the key role of context in understanding the work of individuals. (Clark 2012: 300)

9 Such a process of atomisation is apparent in the EU's push towards personalised paths for learning:

Everyone should be able to follow open learning pathways of their own choice, rather than being obliged to follow predetermined routes to specific destinations. 
This means, quite simply, that education and training systems should adapt to individual needs and demands rather than the other way round. (EU 2000: 8)

10 Although this passage should suggest the adoption of a broader framework on education, one in which everyone is able to choose and pursue her/his own concept of learning and education, I believe something different is at work here to the extent that such "open learning pathways" are to be pursued according to "the demands of the knowledge society and to the need for an improved level and quality of employment" (European Council 2000: §25). Such pathways respond only to the overall requirements of a "peculiar" vision of society. In other words, individual pathways are not the means by which individuals freely choose one way or another, one form of content or another, in an open and transactional interaction with society and environments. Rather, such pathways seem to be the ways in which individuals can best adapt to the pre-specified requirements of the neoliberal vision. Then, within the EU framework, the space for politics is replaced by a space in which anything can be conceived of and enacted in terms of the pre-established services delivered. The only matters up for discussion are the efficiency and performativity of the system under examination:

The relationship between the neo-liberal state and its citizens' has become less a political relationship - that is, a relationship between government and citizens who, together, are concerned about the common good - and more an economic relationship - that is, a relationship between the state as provider and the taxpayer as consumer of public services. (Biesta 2010: 53-4)

11 An additional document, Rethinking Education, delivered by the European Commission in 2012, works in the same vein. Its main passages are symptomatic of the EU's gestures towards education. Let me quote them:

Rethinking Education was set up in 2012 to reform education systems across the EU so as to meet growing demand for higher skills levels and reduce unemployment. What is needed? With labour markets and the demand for skills changing, education systems need to adapt so that they can cope with the rising demand anticipated over the next decade. (European Commission 2012)

The European Commission will continue to take action and pursue discussions designed to ensure that education systems introduce new teaching and learning methods by 2020 that will enable them to equip students with the right skills for employment. (Ibid.)

The point I wish to make clear is that such a document - like the other quoted above - is not a framework created for a specific purpose (namely, how education must face its function of qualification or its commitment to the labour market). I do not object to anything in regards to such a requirement, and it would be an odd opinion indeed if one were to consider education as extraneous to such a pivotal issue. The problem, as simple as it is misguided, is that this aim is pursued as the only function that education must perform. There is nothing wrong with a single institution or some peculiar scholarly perspective that frames education in such terms - indeed, I am also of course arguing for a specific educational logic, and I thus, in a sense, restrict education to one specific logic. However, problems associated with the case exposed here are twofold: a) the institution of which we are speaking is the EU, which is the major actor in European educational processes and practices; in other words, one would expect a wide, multidimensional and inclusive approach from such an institution; and b) in the EU's documents on education, we find no trace of alternative perspectives or, importantly, initiatives aimed at discussing and broadening its approach: all educational actors are expected to enact these 
pre-conceived policies. In these sentences a strong erosion of both ethical and democratic dimensions of education through neoliberal policies is enacted,

any idea of education as a public responsibility and site of democratic and ethical practice is replaced by education as a production process, a site of technical practice and a private commodity governed by a means/end logic - summed up, again, in that supremely technomanagerial question - 'what works?' (Fielding \& Moss 2011: 23-4)

Europe is also facing a skills deficit and, during a time of economic crisis, highlyskilled individuals have a better chance of finding a job. With an estimated $90 \%$ of jobs requiring digital skills in the near future, it is thus essential that education and training systems provide individuals with the required skills. (European Commission 2012)

Now, to first discuss why a different logic is required, let me make an additional remark. One of the main features of such a framework, consistent with the neoliberal narrative, is its tendency to close the loop between the knowledge required to analyse the situation in which education currently finds itself and the knowledge that education should produce. The neoliberal - and EU - narrative tends to speak in a detached and supposedly 'objective' manner in terms of given aims, percentages, tables, data and 'facts' that do not allow any other type of analysis or knowledge to enter the educational debate. Such a choice in turn works to produce a form of knowledge that is strictly functional to its base (Ball 2003). As a corollary, because the aims and purposes of education are given in advance, critical engagement with educational aims, purposes, and the overall framework is neither required nor pursued. Most likely, such a politics of learning will bring about an impoverishment of students' (and teachers') critical agency. In what follows, drawing on Deweyan reflection, I attempt to hint at a different educational logic.

\section{Education as Adaptation}

14 Thus far, I have attempted to argue against the EU educational framework. Here, to first explore why and how Deweyan educational thought may be useful in analysing such an issue while suggesting a different way to conceive of education, let me make an additional remark about the choice to use a Deweyan framework. I begin, by way of introduction, with a passage from the Preface to Democracy and Education:

This book connects the growth of democracy with the development of the experimental method in the sciences, evolutionary ideas in the biological sciences, and the industrial reorganization, and is concerned to point out the changes in subject matter and method of education indicated by these developments. (MW 9: 3)

15 The passage, although it is well known to any Deweyan scholar, is useful in clarifying a question: Dewey's aim, as we know, was never to address education from an abstract, 'philosophical' perspective. Quite on the contrary, in Democracy and Education, Dewey was concerned time and again with how we must understand education as a "necessity of [1]ife" (MW 9: 4), as the title of Chapter One so powerfully suggests. According to the Deweyan framework, education is, above all, a matter of life and death because

the living thing may easily be crushed by superior force, it none the less tries to turn the energies which act upon it into means of its own further existence. If it cannot do so, it does not just split into smaller pieces (at least in the higher forms of life), but loses its identity as a living thing. (MW 9: 4) 
Such a conception of education is not limited to the passage quoted above. On page five, we find an even bolder statement concerning the need for education: "The primary ineluctable facts of the birth and death of each one of the constituent members in a social group determine the necessity of education" (MW 9: 5). Dewey definitely conceived of education as the basis from which human beings face "the problem of how to engage in life" (MW 14: 58). Throughout his work, from How We Think to Knowing and the Known, Dewey clearly recognises the dangers and horrors that dwell in our aleatory world:

Man finds himself living in an aleatory world; his existence involves, to put it baldly, a gamble. The world is a scene of risk; it is uncertain, unstable, uncannily unstable. Its dangers are irregular, inconstant, not to be counted upon as to their times and seasons. Although persistent, they are sporadic, episodic. [...] These things are as true today as they were in the days of early culture. It is not the facts which have changed, but the methods of insurance, regulation and acknowledgment. (LW 1: 43-4; emphasis added)

Such a world "genuine hazard" (LW 1: 62) demands effective responses so that human beings can survive. Human beings, from their first appearance on Earth, have been thrown into such an aleatory world. To survive, they have been called on to transform unsettled and indeterminate situations into ones of more stability and clarity, thereby finding grounding elements through the flow of experience (LW 12: 186). For Dewey, knowledge - and education - are literally a matter of life or death. Thus, in employing a Deweyan framework, we cannot be charged with being removed from reality and uninterested in the concrete realities of society and education. In what follows then, in the light of the Deweyan conception of education and democracy,

I wish to offer some warnings on the weaknesses and risks associated with enacting such policies. I also wish to show that EU framework is inconsistent and, namely, that it is not able to perform its own functions. More specifically, in this section I address the first issue: the EU conception of education as adaptation.

In analysing the account of education Dewey provides in Democracy and Education and in keeping my goal in mind, we can see that Dewey raises two questions that undermine the EU framework: a) the extent to which it is possible to give "purely external direction" (MW 9: 30) to educational processes and practices, and b) the question of the "diversity of stimulation" (MW 9: 90) needed to actually have education. I begin with the former question. The EU's statements that "individuals must adapt to change" and that "Europe's education and training systems" must adapt as well (EU 2000: 3) seem to overestimate opportunities to externally direct educational paths and processes. Education in the EU framework is conceived of as a force from above that shapes individuals by "putting them on the right track" as it were. In my opinion, it is not important if such an approach is labelled by the EU as good for individuals, society, or both. The very problem lies in the fact that such a gesture is inconsistent. In other words, it does not fulfil its own purposes. As Dewey states, in education,

purely external direction is impossible. The environment can at most only supply stimuli to call out responses. These responses proceed from tendencies already possessed by the individual. Even when a person is frightened by threats into doing something, the threats work only because the person has an instinct of fear. If he has not, or if, though having it, it is under his own control, the threat has no more influence upon him than light has in causing a person to see who has no eyes. While the customs and rules of adults furnish stimuli which direct as well as evoke the activities of the young, the young, after all, participate in the direction which their 
actions finally take. In the strict sense, nothing can be forced upon them or into them [...]. Speaking accurately, all direction is but re-direction. (MW 9: 30) a) at an educational level, b) at an ethico-political level, and c) at an existential level. With regards to the educational level, when analysing interactions between individuals and the environment, Dewey focuses on the individual level. He states that the "[t]he environment can at most only supply stimuli to call out responses" and that "[t]hese responses proceed from tendencies already possessed by the individual." Now, it is a given that some of the most Deweyan revolutionary insights come from his challenge to any form of dualism and from his transactional view of individuals and things as emerging from shared experience and communication. Nonetheless, it would be fruitful to focus on the fact that Dewey puts a clear emphasis on the individual angle in this passage. If I am allowed to interpret such a gesture, I believe that what is at stake here is not a theoretical stance - in other words, the transactional approach, whereby individual and society take form together, is not in question. The point rather is an existential and ethico-political one. The Deweyan call is a warning against any totalising thought or allinclusive approach. In other words, it is a call to freedom: "nothing can be forced upon [young people] or into them." Even an individual acting "frightened by threats" acts on "tendencies already possessed by the individual." This is why "we never educate directly, but indirectly by means of the environment." What educators must do is "design environments for the purpose" (MW 9: 23). The EU, conversely, takes the environment as a given and then requires the individual to adapt to such an environment by means of education. As we can see, the EU turns education on its head, thus simultaneously limiting both individuals and collective educational possibilities. Such a limitation also works to undermine EU goals of innovation and achievement because every achievement, in Deweyan conception, is based on personal commitment - the "tendencies already possessed by the individual" (MW 9: 30) and "shared common interest" (MW 9: 92), or the very things that EU educational politics removes. this point in the following section, I wish to highlight here that Dewey repeatedly draws our attention to the relationship between meaning creation and shared experience. As he states, "things gain meaning by being used in a shared experience or joint action" (MW 9: 20). What is important to bear in mind is that such a "shared experience or joint action" cannot - by definition - be an experience shaped from above in response to pre-specified demands. For sharing to occur, we need freedom (the freedom to interact and the freedom to project possible aims and goals). In Democracy and Education, Dewey expends crucial words on meaning creation, going so far as to state that,

There is no limit to the meaning which an action may come to possess. It all depends upon the context of perceived connections in which it is placed; the reach of imagination in realizing connections is inexhaustible. (MW 9:215)

In this passage, we come to see how action does not have meaning in itself; action does not carry any meaning because "it all depends upon the context of perceived connections in which it is placed." In other words, the human capacity to create meaning - in Deweyan words, "the capacity for constantly expanding the range and accuracy of one's perception of meanings" (MW 9: 130) - is potentially inexhaustible. A limitation in connections flows inevitably from narrowing down the creation and perception of meaning, namely, in narrowing down the broadening of "the meaning-horizon" (MW 9: 84) that Dewey so powerfully calls for.

European Journal of Pragmatism and American Philosophy, VIII-1 | 2016 
Such narrowing down has strong effects on the subject as well. If, according to Dewey, "the self is not something ready-made, but something in continuous formation through choice of action [...] [and] the generous self consciously identifies itself with the full range of relationships implied in its activity" (MW 9: 361-2), then by limiting the choices the self can effect and its range of relationships, the EU ends up also limiting the contribution that the self can make to the formation and development of society. This point leads me to discuss the second feature of EU educational politics, that is, the atomisation of educational practices.

\section{Atomising Education}

While one could argue that the individuation of educational processes and practices pursued by the EU constitutes a step towards the free and open development of learning possibilities - in the end one can claim that individuals are able to choose what, when and how to learn through such a path - it is my contention that this gesture entails a strong limitation on educational possibilities, both individual and social, and that such a freedom is only an ostensible one. In this section, I wish to argue that the EU's gesture entails the restriction of an individual's educational opportunities and even a threat to democratic society as a whole.

The atomisation of educational practices affects two related levels: a) the level at which individuals and society shape one another and at which, in a sense, both come into the world together; and $b$ ) the level at which meaning arises. The first level is one of the most frequently analysed by Deweyan scholars. One of the most important insights of Dewey's transactional approach is his account of democracy as "primarily a mode of associated living, of conjoint communicated experience" (MW 9: 93). Through such a mode, as we know, through "more numerous and more varied points of contact" between people who share interests and stimuli, "a liberation of powers" (MW 9: 93) is achieved. This occurs because "[t]he individual in his isolation is nothing; only in and through an absorption of the aims and meaning of organized institutions does he attain true personality" (MW 9: 101). Thus, it is in a sense surprising how the cradle of democracy lacks such a pivotal dimension in its educational processes. In what follows, however, I wish to focus on another unfortunate outcome of atomisation, an outcome that affects the creation of meanings. Let us pay attention to the following passage:

There is no limit to the meaning which an action may come to possess. It all depends upon the context of perceived connections in which it is placed; the reach of imagination in realizing connections is inexhaustible. (MW 9:215)

Here we come to see how action, namely the "most basic category" (Biesta \& Barbules 2003: 9) of the Deweyan approach, has no meaning in itself. Of course, actions are enacted in determinate contexts aimed at realising determined purposes. However, this does not complete the meaning of our actions. In Deweyan terms, meanings are always open to further creation/interpretation (Garrison 1996). However, at the very same time, they are always at risk of collapsing, of imploding, or of being consumed. Importantly, these meanings may be unlimited. Education, for Dewey, is also the means through which human life gains its ever-open and ever-possible meaning. The problem is that such an ever-present potentiality of further meanings can be enacted only when imaginations can realise actual connections, as such a potentiality depends on "the context of perceived connections in which it is placed." Stated negatively, when such connections are impeded 
or removed, the creation of meanings is curtailed as well. Such an atomisation of educational practices and processes also threatens thinking itself. Despite the grouping of thinking and reflective thought that has largely appeared in interpretations of his work, Dewey highlights in several passages how thinking entails an inescapable uncertainty at its core. In his words, "to consider the bearing of the occurrence upon what may be, but is not yet, is to think" (MW 9: 153). Such an uncertainty, faithful to his philosophy, also constitutes the door to growth and education: the possibility, in Granger's words, "[to] liberate and expand the potential meanings of things" (Granger 2006: 7).

A number of scholars have analysed meaning creation in Deweyan work. Due to space restrictions, I wish to linger only on the relationships between meaning, possibilities and newness. To make my point I will draw from Garrison's, Granger's and Waks' (converging) accounts.

In a 1994 article, Jim Garrison, in discussing the function of art, states, "the 'truth' of art, of poetry, is that it can disclose the beauty of meaningful possibilities that are concealed beneath the mask of the actual, the ordinary, the everyday" (Garrison 1994: 3). He then goes on to state that such a function pursued by "expansive imagination" is essential for freedom to exist:

A lack of imagination and thereby a sense of possibility is the greatest oppression there is. It is here that any critical and transformational theory of education must take its departure [...]. Without an expansive imagination, one willing to go beyond approved limits, it is impossible to be free. (Ibid.: 3)

It is crucial to bear in mind that freedom, according to Dewey, serves as the basis from which we can conceive of communication, democracy and growth. Without the possibility of expanding freedom, all Deweyan work would end in emptiness. In fact, we can even say that his work constitutes a continuous endeavour to understand and expand freedom and its conditions.

The expansion of meanings is also the point of departure of Granger's account: "In learning to conduct more of everyday experience in an artful manner, we increase our ability to liberate and expand the potential meanings of things" (Granger 2006: 7). By integrating art into everyday experience, the world comes to be presented "in a new and different perspective" (Ibid.: 104). This different perspective is also Waks' point. In his "Agency and Arts: John Dewey's Contribution to Pragmatic Cosmopolitanism," Waks highlights the role of art as the "channel for spontaneous, pre-rationalized initial expressions of the "whole' person" (Waks 2009: 120) and as an essential component in the "opening [of] new vistas and widening perception" (Ibid.: 121). According to Waks' account, art is important both to overcome separation within a subject's experience and to foresee unnoticed perspectives.

30 Such a possibility is quintessentially pedagogical to the extent to which we conceive of education as the means by which we may pursue and welcome newness (see Garrison 1996, 2005; Biesta 2006, 2007). Now, it is worthy to note that Dewey conceives of "imaginative experience" and education along the same lines; an imaginative experience "is what happens when varied materials of sense quality, emotions and meanings come together in a union that marks a new birth in the world" (LW 10: 272). Moreover, he writes:

A sense of possibilities that are unrealized and that might be realized are, when they are put in contrast with actual conditions, the most penetrating "criticism" of the latter that can be made. It is by a sense of possibilities opening before us that 
we become aware of constrictions that hem us in and of burdens that oppress. (LW 10: 349 )

Such an account goes hand in hand with the Deweyan interpretation of education as an "emancipation and enlargement of experience" (MW 6: 301). Such an "emancipation and enlargement of experience," following Garrison, Granger and Waks' converging interpretations, simultaneously welcomes newness (or, in Deweyan terms, "a new birth in the world") and the recovery of the unity of the subject's experience.

There is also another question at stake: the "diversity of stimulation" (MW 9: 90) that is needed to actually have education. Let us pay attention to the following passage:

Diversity of stimulation means novelty, and novelty means challenge to thought. The more activity is restricted to a few definite lines as it is when there are rigid class lines preventing adequate interplay of experiences - the more action tends to become routine on the part of the class at a disadvantage, and capricious, aimless, and explosive on the part of the class having the materially fortunate position. (MW 9: 90)

Here, Dewey furnishes in advance a strong critique of the EU neoliberal educational framework. In this passage, the lack of "diversity of stimulation" is potentially "explosive." In Deweyan educational philosophy, equilibrium can only be attained through growth.

This passage is even more interesting when considering its final section. The lack of "diversity of stimulation" and "adequate interplay of experiences" is not only damaging to those socially or economically disadvantaged; importantly, it is also dangerous for those who assume a "materially fortunate position." In other words, such a lack is a threat to society as a whole. This is why Dewey states that,

the intellectual variations of the individual in observation, imagination, judgment, and invention are simply the agencies of social progress, just as conformity to habit is the agency of social conservation. (MW 9:306)

The individualisation and atomisation of educational processes and practices pursued by the EU also implies a progressive eclipse of the democratic and ethical dimensions of educational processes and practices. I wish to make clear from the outset that I am not claiming that the EU has no ethics or sense of democracy; that would be a senseless claim. My point is, of course, slightly more nuanced, touching on the (hidden) ethics of the neoliberal framework and the current lack of democracy in education. The "open learning pathways" (EU 2000: 8) towards which EU calls for, most likely work to cut possibilities to concretely share contents, ways of learning and individual's choices. The public dimension of educational processes is, then, severely reduced by EU educational politics in that EU does not work to promote public debates about the aims of education. Such aims, in fact, are pre-established, along with the overall framework in which individuals as well as institutions are called to think and act. Individual needs and demands, too, are only conceived of in such a neo-liberal framework, thus denying the ethical dimension of educational processes, one in which the debate about the ends of education is promoted and sustained.

To cut to the chase, the problem with the EU framework is that it presents itself as unique and inevitable. Then we only have an appearance of openness. The EU choice of a specific concept of education is not presented as an - ethical - choice, but as a matter of fact. Additionally, educational actors and institutions are required to follow pre-determined paths. There is no dynamic coming from below, where below are educators, teachers and 
students. Moreover, despite several claims made about the connections between training and society's challenges, it is all too clear how such connections will be enacted based on a determinate economic vision of society. The problem with this lies not so much in the specific lens chosen, but in the very fact that such a broad institution adopts only one lens on education, thus erasing other approaches. Again, it is here worth quoting Dewey at length:

In final account, then, not only does social life demand teaching and learning for its own permanence, but the very process of living together educates. It enlarges and enlightens experience; it stimulates and enriches imagination; it creates responsibility for accuracy and vividness of statement and thought. A man really living alone (alone mentally as well as physically) would have little or no occasion to reflect upon his past experience to extract its net meaning. (MW 9: 9)

Then, if education also entails the enhancement of social progress and transformation, "novelty" and the "diversity of stimulation" must be considered key educational features.

Education is the place where our lives and the life of society take form. When we conceive of education from a pre-established stance, we conceive of living before living can show its own possibilities. Society functions in the same way. In fostering only one concept of education, we crystallise, so to speak, the current form of society and existing power relationships. Thus, education, to the extent that it is concerned with freedom and justice, must also be concerned with otherness and possibilities and namely with the space that has not yet been thought of. However, to the extent that the meaning of education lies in transformation and that education is concerned with justice, education must be concerned with the ungraspable openness of our thought. Education must demand work to go beyond what we and society currently are. As educators, we must continually ask whether our views of education are inclusive and good enough to meet and manage this challenge. Through such engagement, without challenging given "forms of life," education is at risk of becoming a means of facilitating the progressive impoverishment of living and the perpetuation of injustice and inequality into the future.

This is not the place to discuss the relationship between the real nature of today's economy and the fairy tale version of it, though opportunities to create new processes in the globalised world are, in my view, intentionally overstated. That globalisation has led to a larger space for creativity in education and in the workplace at large is all too apparent. The weight of international associations such as the EU, with their strong influence on countries, and increasing levels economic inequality point in the opposite direction. The real decisions on education are most likely made by fewer people than in the recent past. The EU, for example, hardly creates a space for sharing knowledge and experience on education, as such a space starts with teachers, educators, and key local actors in the field of schooling and education. Rather, the EU aims to govern the educational process through pervasive penetration into schools, educational departments, government agencies dedicated to education, and families. This approach is a mistake, and not merely from a humanistic and old-fashioned perspective.

I am concerned with the fact that when education is virtually narrowed down to just one function - i.e., employability - we lose sight of the variety, complexity and unpredictability of life and education. In other words, I hold nothing against a call for the usefulness of educational paths - from a Deweyan perspective, doing so would be an odd gesture. My main concern lies in the way and extent to which such usefulness is to be conceived. My point is that if education is required to respond only to specific demands of 
the labour market, thus producing a predetermined set of skills, it then fails to prepare individuals for the declared future and challenges. The EU should be aware that newness, the challenging of perspectives, and shared interests are essential, not only to education but also to the development of society, which depends on the presence of variety, as biology and social sciences as well have shown, throughout the past two centuries, time and again.

\section{BIBLIOGRAPHY}

ALEXANDER R., (2011), “Evidence, Rhetoric and Collateral Damage: The Problematic Pursuit of 'World Class' Standards," Cambridge Journal of Education, 41, 3, 265-86.

AU W., (2008), "Devising Inequality: A Bernsteinian Analysis of High-Stakes Testing and Social Reproduction in Education," British Journal of Sociology of Education, 29, 6, 639-51.

BALL S. J., (2003), "The Teacher's Soul and the Terrors of Performativity," Journal of Education Policy , 18, 2, 215-28.

BEUKel E., (2001), "Educational Policy: Institutionalization and Multi Level Governance," in Andersen S., \& Elliassen K., (eds.), Making Policy in Europe, London, Sage, 124-39.

BIESTA G. J. J., (2006), Beyond Learning. Democratic Education for a Human Future, Boulder, CO, Paradigm Publishers.

BIESTA G. J. J., (2007), “The Education-Socialisation Conundrum or 'Who Is Afraid of Education?', Utbildning \& Demokrati, 16, 3, 25-36.

BIESTA G. J. J., (2009), “Witnessing Deconstruction in Education: Why Quasi-Transcendentalism Matters," Journal of Philosophy of Education, 43, 3, 391-404.

BIESTA G. J. J., (2010), Good Education in an Age of Measurement: Ethics, Politics, Democracy, Boulder, Co, Paradigm Publishers.

BIESTA G. J. J., (2015a), “What is Education For? On Good Education, Teacher Judgement, and Educational Professionalism," European Journal of Education, 50, 1, 75-87.

BIESTA G. J. J., (2015b), "Freeing Teaching from Learning: Opening Up Existential Possibilities in Educational Relationships," Studies in Philosophy and Education, 34, 3, 229-43.

BIESTA G. J. J., \& N. C. BURBUles, (2003), Pragmatism and Educational Research, Boston, Rowman \& Littlefield Publishers.

BURBULES N., \& C. TORRES, (eds.), (2000), Globalization and Education: Critical Perspectives, London, Routledge.

ClARKe M., (2012), “The (Absent) Politics of Neo-Liberal Education Policy," Critical Studies in Education, 53, 3, 297-310

COMPTON M., \& L. WEINER, (eds.), (2008), The Global Assault On Teaching, Teachers, and Their Unions: Stories for Resistance, New York, NY, Palgrave Macmillan. 
CONNELl R., (2013), "The Neoliberal Cascade and Education: An Essay on the Market Agenda and its Consequences," Critical Studies in Education, 54, 2, 99-112.

DEWEY J., (1969-1991), The Collected Works, 1882-1953, edited by Boydston J. A., 37 vols., Carbondale and Edwardsville, IL, Southern Illinois University Press.

EU, (2000), A memorandum on lifelong learning Commission of European Communities, available at [arhiv.acs.si/dokumenti/Memorandum_on_Lifelong_Learning.pdf].

EUROPEAN COMMISSION, (2010), Communication from the Commission Europe 2020: A strategy for smart, sustainable and inclusive growth, available at

[eur-lex.europa.eu/LexUriServ/LexUriServ.do?uri=COM:2010:2020:FIN:EN:PDF].

EUROPEAN COMMISSION, (2012), Rethinking Education, available at

[ec.europa.eu/languages/policy/strategic-framework/rethinking-education_en.htm].

EUROPEAN COUNCIL, (2000), Lisbon European Council Presidency Conclusion 2000, available at [ europarl.europa.eu/summits/lis1_en.htm].

FIELD J., (1998), European Dimensions of Education and Training, London, J. Kingsley.

FIELDING M., \& P. MOSS, (2011), Radical Education and the Common School: A Democratic Alternative, London, Routledge.

GARRISON J., (1994), “Dewey, Eros and Education,” Education \& Culture, IX, 2, 1-5.

GARRISON J., (1996), “A Deweyan Theory of Democratic Listening,” Educational Theory, 46, 4, 429-51.

GARRISON J., (2005), “A Pragmatist Conception of Creative Listening to Emotional Expressions in Dialogues Across Differences," Philosophy of Education, Howe K. R., (ed.), Indiana, Indiana University Press.

GRANGER D., (2006), John Dewey, Robert Pirsig, and the Art of Living: Revisioning Aesthetic Education, New York, Palgrave Macmillan.

KEELING R., (2006), “The Bologna Process and the Lisbon Research Agenda: The European Commission's Expanding Role in Higher Education Discourse," European Journal of Education, 41, 2, 203-23.

LAWN M., \& B. LINGARD, (2002), “Constructing a European Policy Space in Educational Governance: The Role of Transnational Policy Actors,” European Educational Research Journal 1, 290-307.

MARGINSON S., (1997), Markets in Education, Sydney, Allen \& Unwin.

MASSCHELEIN J., \& M. SIMONS, (2008), “The Governmentalization of Learning and the Assemblage of Apparatus," Educational Theory, 58, 4, 391-415.

MURPhy M., (2003), "Covert Action? Education, Social Policy and Law in the European Union,” Journal of Education Policy, 18, 5, 551-62.

NO'VOA A., (2000), “The Restructuring of the European Educational Space: Changing Relationships Among States, Citizens and Educational Communities," in Popkewitz T., (ed.), Educational Knowledge: Changing Relationships Between the State, Civil Society, and the Educational Community, Albany, NY, SUNY Press, 31-57.

RYBA R., (1992), “Toward a European Dimension in Education: Intention and Reality in European Community Policy and Practice," Comparative Education Review, 36, 1, 10-24.

SIMONS M., (2006), "Learning as Investment: Notes on Governmentality and Biopolitics," Educational Philosophy and Theory, 38, 4, 523-40. 
WAKS L. J., (2009), “Inquiry, Agency and Arts: John Dewey’s Contribution to Pragmatic

Cosmopolitanism," Education \& Culture, 25, 2, 115-25.

\section{NOTES}

1. References to John Dewey's published works are to the critical edition, The Collected Works of John Dewey, 1882-1953, edited by Boydston J. A., Carbondale and Edwardsville, Southern Illinois University Press, 1967-1991, and published in three series as The Early Works 1882-1899 [EW], The Middle Works 1899-1924 [MW], and The Later Works 1925-1953 [LW].

2. For a detailed analysis of this issue, see Murphy 2003; and Keeling 2006.

3. The 2001 reauthorization of the Elementary and Secondary Education Act in the U.S.

\section{ABSTRACTS}

At least since the Lisbon Memorandum on Lifelong Learning, European education has been increasingly framed in terms of a neoliberal rallying cry. Such a gesture has widely affected education and schooling in Europe and has pushed educational institutions and processes towards a significant transformation. Such a transformation - and this is my point - is anything but benign: it implies a lack of invaluable educational features such as critical agency, democratic sharing, and meaning creation. In this paper, I wish to address this issue in the light of Dewey's thought and philosophy of education, mainly in reference to his masterpiece Democracy and Education. In particular, drawing from the Deweyan conception of democracy and meaning creation, I wish to argue that a different conception of education, where education is not rationed, individualised or commodified, is required. I also argue that the EU framework on education is inconsistent, as it is not able to fulfil its own goals. By enacting the EU educational framework, we indeed lose sight of the variety, complexity and unpredictability of education and society.

\section{AUTHOR}

\section{VASCO D'AGNESE}

Seconda Università di Napoli

vasco.dagnese[at]unina2.it 